\title{
THE USE OF ROLE PLAY TO IMPROVE STUDENTS' SPEAKING SKILL
}

\author{
Dela Octavia Ayuningtias ${ }^{1}$, Wulandari ${ }^{2}$, Yana $^{3}$ \\ ${ }^{1}$ IKIP Siliwangi \\ ${ }^{2}$ IKIP Siliwangi \\ ${ }^{3}$ IKIP Siliwangi \\ ${ }^{1}$ dellaoctavia15@gmail.com, ${ }^{2}$ wulandari19071997@ gmail.com, ${ }^{3}$ yanaenglish.edu@ gmail.com
}

\begin{abstract}
This research entitled the use of Role Play Technique to improve students' speaking skill. The objective of the research is to improve Speaking skill using Role Play technique. This research used Classroom Action Research. Role play can be trusted to help students speaking ability. The population of the research were the students at SMKN 3 Karawang in Academic years 2017 - 2018. The total population of students in this academic years is 300 Students. The number of sample was 30 students. The data was gathered from test and observation. The average score of test was Cycle I 58.08 and Cycle II 58.06. After the implementation of Role Play activities in every cycle, the students' speaking score were getting better. It can be seen from the result of students' average score Cycle I was 83.07 and Cycle II was 77.08. It can be concluded that Role play can improve students' speaking skill.
\end{abstract}

Keywords: Role play, Speaking, CAR

\section{INTRODUCTION}

English speaking skill is one of the skills of language to be required in global interaction or communication. It can not be denied that English speaking skill becomes the most favorite skill needed for students in Indonesia recently. Students must get communication in English. However, it is not convenient to master all skills. There are so many difficulty in mastering each skill. Speaking is an activities use from someone to communicating with other(s). It take place everywhere and has become part of our daily activity. When someone speaks, he or she interacts and use the language to express his or her ideas, feeling and thought. He or she also shares information with other(s) through communication. Speaking skill is partly a reflection of someone whether he/she masters this language or not. Thus, it can be concluded that speaking as the most important skill of all four skills (Ur, 1996) cited in Aristy, Hadiansyah, \& Apsari (2019). Liu, Xu (International Education Studies, v3 n1 p136-144 Feb 2010)

English as a tool of communication has been playing an important part in acquiring cultural, scientific and technical knowledge, for collecting worldwide information and carrying out international exchange and cooperation. Improving the level of English spoken student is becoming increasingly important. Based on the theory of motivation, Richard E. Mayer and excess play roles on motivational aspects of learning, this paper not only explores some theories communicative teaching methods, but also prove the importance of motivation to learn. Two types of English language teaching activities for oral English classes designed which are oral English tests and role playing activities. The purpose of this study is to raise the motivation of students to speak English. And the project hypothesis is that using role play activities more effective in motivating students to speak English rather than using oral English test. Researchers 
divided the students are new students of Beijing into two groups - Target group and control group. And the researcher conducted the study using observation notes, questionnaires and interview data collection methods. Through a four-week study, it was proven that students in the Target Group who used role playing activities became more interested in speaking English than students in the Control Group who used oral English tests. So the results of this research, we know that in our Chinese universities, teachers can use some communicative classroom activities such as role play to raise the motivation of students to speak English. There are also some limitations of this research for example, because the sample size was small, the results might not be typical; and the time of the research was too short, so maybe there were some unstable data.

Through pre-observation it is known that many students, especially in SMKN 3 Karawang said that speaking is the most difficult skill to master. It require not only knowledge, in terms of mastering vocabulary and grammar, but also a desired and confidence in speaking. The problem appears in the desired of the students in practice to speak English. Most of them don't have any willingness to speak. If they are asked from the teacher to speak up, they just save quiet and say nothing. And when the researchers asked them during the interview, the reason are various. Some students say that they can't spek up. because they are lack of vocabulary and they also don't have any confidents to speak. This implies that the difficulties of mastering speaking is due to her less of vocabulary and confidence.

The researchers also found the same information when they interviewed English teacher about the reason why the students in this classroom don't want to speak. English teacher said, "the students in vocabulary mastery is less, so, if they are less of vocabulary,automatically, their speaking skills are also less". This statement shows that their teacher knows that their students' vocabulary mastery is very limited, so if they have limited vocabulary, they will have limited competence in speaking.

In teaching speaking, the teacher needs a good technique to improve students' speaking skill. One of them is by using role play. Playing the role is a method of acting out specific ways to interact with others in an imaginary situation (Byrne, 1986) and to promote interaction in the classroom and increase motivation (Ladousse, 1995). In addition, Budden (2006) says that role playing is an activity of speaking when you put yourself into someone else or put yourself in an imaginary situation. Based on the explanation above, role play is not only used for interactive teaching in the classroom but also to stimulate students in real life situations. Furthermore, Byrne (1986), role play can be grouped into two forms, playing written and unwritten roles.

Cameron-Jones, M. In education, action research is research carried out by practitioners with a view to improving their professional practice and understanding it better. This paper concentrates mainly on classroom action research by inservice teachers, although this approach can also be realized in pre-service training courses and can embrace various professional practices outside the classroom. Classroom action research is now seen as the primary means of professional development, particularly in the course and innovative exercise programpositions and, as such, it attracts the support and growing interest. As This approach is becoming more widespread, the idea of the teacher-as-researcher becomes more developed and more fully understood. This paper outlines the origins of the approach, describe the features typical, provide examples, and presents two questions for Scotland: (1) how this approach can contribute to the development of in-service? (2) how to contribute to the development of research? 


\section{METHOD}

In this research, the researchers used CAR ( Classroom Action Research). According to (Bashir \& Azeem, 2011)(Suryani, 2015)(Cameron-Jone, 1983), action research is research conducted by researchers with a view to improve the professional practice of researchers and understand it better. There are four stages of each cycle, they are: (1) the planning of the action, (2) the implementation of the action, (3) classroom observation and (4) reflecting of the action (Kemmis \& McTaggart, 1988). This research was conducted at SMKN 3 Karawang, involving 30 students with 20 females and 10 males of class X Accounting academic year of 2017/2018.

\section{Planning}

In the plan stage, the researchers prepared the research instruments, designed the lesson plans, selected the Role play, set the criteria of success and made the research schedule.

\section{Implementing}

In this stage, the researchers act as a teacher who implements the action, while the classroom English teacher takes a role as an observer who observes the action implementation.

\section{Cycle 1}

In this section, the researchers applied the treatment to the students based on the lesson plan prepared through script memorization. There are steps made in implementing the role play memorization technique. The steps are: (1) prepare script drama or dialogue , (2) ask the students to the division of roles, (3) ask the students to do memorization script, and (4) lead the students to performance with decoration equipment.

\section{Meeting 1}

The First, researchers ask students about role playing. Play drama videos about friendship. It was played 3 times. The first round aims to allow students to enjoy drama first. After that, the teacher submits a sheet containing empty words / phrases and asks students to fill them in. Then students must collect the sheets. After that, the teacher delivered the second sheet. The second drama is the reality of life. Then, they have to fill in the blank sheet again. They must collect again. The last drama is The Princess Siger. It is done with the same treatment.

\section{Meeting 2}

In the second meeting, the teacher gave a different drama to the students. In this meeting, the material was about comparison and contrast. Here, the same treatment as meeting 1 was applied to the students. In the last 15 minutes, the students were asked to know their improvement in speaking skill.

\section{Cycle 2}

\section{Meeting 1}

In this meeting, students are taught about the role of the antagonist and protagonist. Here, the teacher tries to change care. In this section, the teacher exemplifies the role of the antagonist and protagonist many times. until students are able to play it themselves.

\section{Meeting 2}

In this meeting, the teacher give the same treatment to the students, as the meeting before.

\section{Observation}

In this study, observing students' speaking abilities was done to obtained data and to find out how well the application of English role playing techniques could achieve the 
research objectives. At this stage, researchers collect data related to the implementation of actions using several instruments. The first is an observation checklist filled in by observers. The second is a field note made by the teacher. Both instruments are used to obtain data related to student participation. The third is the results of speaking tests conducted by students at the end of each cycle, aiming to obtained data about students' speaking abilities. The fourth is the result of a questionnaire given to students at the end of the study, which aims to find information about student responses to the use of English role playing technique.

\section{Reflection}

At this stage, the researchers reflect data from actions that reflect the implementation of the cycle obtained through observation and implementation techniques to master speaking English in the teaching-learning process. The results of the criteria with the success criteria designed. Criteria for success have been reached. If it fails, the researcher will continue the study to the next cycle.

\section{RESULTS AND DISCUSSION}

\section{Results}

The result of the research showed that there was improvement from Cycle I to Cycle II in the students' participation in introduction, discussion and practice. The average score of test was Cycle I 58.08 and Cycle II 58.06. After the implementation of Role Play activities in every cycle, the students' speaking score were getting better. It can be seen from the result of students' average score Cycle I was 83.07 and Cycle II was 77.08.

\section{Table 1.Test Results in Cycle I and Cycle II}

\begin{tabular}{lcc}
\hline \multicolumn{1}{c}{ Explanation } & Cycle I & Cycle II \\
\hline $\begin{array}{l}\text { The highhest } \\
\text { score }\end{array}$ & 85 & 80 \\
$\begin{array}{l}\text { The lowest } \\
\text { score }\end{array}$ & 25 & 25 \\
$\begin{array}{l}\text { The average } \\
\text { score }\end{array}$ & 58.8 & 58.6 \\
\hline
\end{tabular}

Table 1.Test Results after Implementation Role play Cycle I and Cycle II

\begin{tabular}{lcc}
\hline \multicolumn{1}{c}{ Explanation } & Cycle I & Cycle II \\
\hline $\begin{array}{l}\text { The highhest } \\
\text { score }\end{array}$ & 95 & 95 \\
$\begin{array}{l}\text { The lowest } \\
\text { score }\end{array}$ & 75 & 45 \\
$\begin{array}{l}\text { The average } \\
\text { score }\end{array}$ & 83.07 & 77.08 \\
\hline
\end{tabular}


Based on the results obtained on student learning outcomes, student activity and teacher activities in cycle II showed a significant increase due to the use of role play.

\section{Discussion}

This study purpose to improve students' speaking skills by using role playing techniques. Through two cycles, the learning process is carried out and runs well in tenth grade students of SMK 3 Karawang. Based on the scores obtained, in cycle II it has reached the target score. Therefore researchers will not proceed to cycle III. It is evident that using this method can improve students' speaking abilities in English.

\section{CONCLUSION}

Taken base on the data above. First, role playing can be considered as the right technique to improve students' speaking skills, especially accounting class X students in SMK 3 Karawang. This test is given in preliminary studies, Cycle I, and Cycle II. Second, from the revised teaching strategy in Cycle II, it was found that role playing techniques would further improve English speaking skills. Third, playing a role can foster confidence in students to speak English. The results of observations show that students can active participate in teaching and learning activities carried out using role playing techniques. Fourth, active participation in student learning shows that they will be able to build their enthusiasm in learning. Thus, it can be seen from the results of the role playing performance of students who can be good technical choices in teaching and improving English speaking skills.

\section{ACKNOWLEDGMENTS}

Alhamdulillahirabbil'alamin, thanks to Allah SWT who has enabled to finish this paper. Peace and salutations are always for Rasulullah SAW. Thanks to family and our lecturer during finishing this paper.

\section{REFERENCES}

Aristy, I., Hadiansyah, R., \& Apsari, Y. (2019). Using Three Step-Interview To Improve Students' Speaking Ability. Project, 2(2), 74-79.

Bashir, M., \& Azeem, M. (2011). British Journal Of Arts And Social Sciences. Issn, 2(1).

Cameron-Jone, M. (1983). A Researching Profession? The Growth Of Classroom Action Research. Scotland: Moray House College Of Education.

Kemmis, S., \& Mctaggart, R. (1988). The Action Research Planner, 3rd. Victoria: Deakin University.

Mundriyah, M., \& Parmawati, A. (2016). Using Think-Pair-Share (Tps) To Improve Students'writing Creativity (A Classroom Action Research In The Second Semester Students Of Stkip Siliwangi Bandung). P2m Stkip Siliwangi, 3(2), 84-91.

Studies, I. E. (1981). Arousing The College Students ' Motivation In Speaking English Through Role-Play. Ccse, 3(1), 136-144.

Suryani, L. (2015). ELTIN Journal, Volume 3/II, October 2015. ELTIN JOURNAL, Journal

Of English Language Teaching In Indonesia, 3(October), 106-109. 